\title{
Uroperitôneo em bovino da raça Nelore: relato de caso
}

Mirian Rodrigues", Fabio Henrique Bezerra Ximenes, José Ricardo Barboza Silva, Isabela Docek de Faria, Bianca Paola Santarosa, Gustavo Gomes Macedo, Noeme Sousa Rocha, Alexandre Secorun Borges, Ana Liz Garcia Alves, Celso Antonio Rodrigues

Faculdade de Medicina Veterinária e Zootecnia, Universidade Estadual Paulista (UNESP), Botucatu, SP, Brasil

*Autor correspondente

e-mail: mrodrigues@fmvz.unesp.br

\section{Resumo}

A urolitíase obstrutiva apresenta alta incidência e relevância em ruminantes criados sob manejo intensivo. Os machos são mais acometidos devido à anatomia da uretra peniana, que é longa e sinuosa. A dieta rica em grãos, presente nos confinamentos, geralmente apresenta desequilíbrio Ca:P, o que predispõe a formação dos urólitos, dentre outros fatores. 0 presente relato descreve um caso de urolitíase obstrutiva com consequente ruptura de bexiga em bovino Nelore originado de FIV (fertilização in vitro), macho, não castrado, 13 meses de idade, $600 \mathrm{~kg}$, criado sob manejo intensivo, encaminhado ao Hospital Veterinário da FMVZ-UNESP/Botucatu. A queixa principal do proprietário era apatia, anorexia, oligodipsia, fezes ressecadas, polaquiúria seguida de anúria e dor abdominal. Os valores de ureia e creatinina do líquido peritoneal foram de $276 \mathrm{mg} / \mathrm{dL}$ e 33,5mg/dL respectivamente. A bioquímica sérica revelou azotemia, sendo os valores de ureia 195,1 mg/dL e creatinina 15,65 mg/dL. Após avaliação clínica e constatação de ruptura da bexiga dorso-caudal por palpação retal, optou-se pela cistorrafia realizada por laparatomia via fossa paralombar direita. A sutura foi feita às cegas, em padrão simples interrompido, com fio Vycril ${ }^{\circledR} 2-0$, e o tratamento pós-operatório constituiu-se de ceftiofur (5 mg.kg-1, $\mathrm{SID}$, IV), flunixin meglumine $\left(1,1 \mathrm{mg} \cdot \mathrm{kg}^{-1}\right.$, BID, IV), fluidoterapia parenteral com Ringer Simples e transfaunação. Embora a bexiga estivesse repleta de urina, o fluxo urinário não foi restabelecido. Realizou-se a sondagem uretral com sonda nasogástrica humana número 16. Devido ao processo obstrutivo provocado pela presença de cálculo, a sondagem não foi efetiva. Devido ao mau prognóstico, realizou-se a eutanásia. Ao exame necroscópico, evidenciou-se quantidade acentuada de urina na cavidade abdominal, áreas de necrose na região da ruptura da vesícula urinária, além de aderência aos órgãos adjacentes (alças intestinais e mesentério). No trajeto proximal da uretra peniana havia um cálculo sólido, de $0,9 \mathrm{~cm}$ de altura e 0,75 cm de largura. No tórax havia espessamento da pleura, com ponto de aderência, além de peritonite fibrinosa multifocal. No rim direito havia congestão 
da medular e no esquerdo, acentuado grau de pielonefrite, com aspecto pálido da medular e cortical, além da presença de conteúdo supurativo. Sabe-se que o prognóstico varia de reservado a ruim, dependendo da clínica instalada. No presente relato, o tempo prolongado para o diagnóstico de obstrução uretral acarretou na ruptura da bexiga e consequente óbito do animal, embora tenha sido feita a laparotomia para cistorrafia. A eutanásia foi indicada devido ao mau estado geral do animal, ao uroperitônio com peritonite fibrinosa instalada, que foi comprovada na necropsia. 0 prognóstico em casos de uroperitônio é de reservado a ruim, dependendo do comprometimento sistêmico. Portanto, a prevenção deve ser instituída nas criações, tanto de manejo intensivo como extensivo, pelo balanceamento da dieta, especialmente pelo equilíbrio da relação Ca:P, e pelo fornecimento adequado de água a fim de evitar perdas econômicas e genéticas. 